\title{
Low birth weight was the most dominant predictor associated with stunting among children aged 12-23 months in Indonesia
}

Ni Ketut Aryastami ${ }^{1 *}$ (D), Anuraj Shankar ${ }^{2}$, Nunik Kusumawardani ${ }^{3}$, Besral Besral ${ }^{4}$, Abas Basuni Jahari ${ }^{3}$ and Endang Achadi ${ }^{5}$

\begin{abstract}
Background: Stunting among toddlers is highly prevalent in Indonesia. As a chronic malnutrition problem, stunting is closely related to internal (maternal health) and external factors such as feeding practices, illness and socio-economics of the community. The purpose of this study was to analyze the relationship between low birth weight (LBW), child feeding practices and neonatal illness with stunting among Indonesian toddlers.

Methods: For this study, we took data from the 2010 Indonesian National Basic Health Survey (RISKESDAS). Totally 3024 children aged of 12-23 months included in this analysis. Stunting was measured using standardized body length and was defined based on criteria from WHO Anthroll.PC2007. Data analysis was done through bivariate and multivariate logistic regressions.

Results: The results showed that the prevalence of stunting among Indonesian toddlers (12 23 months) was 40.4\%. Early initiation of breast-feeding and exclusive breast feeding was experienced by $42.7 \%$ and $19.7 \%$ of the babies. More than half of the babies were given pre-lacteal feeds, while early complementary feeding was given to $68.5 \%$ of the subjects. Multivariate analysis showed infants born with LBW were 1.74 times more likely to be stunted (95\% Cl 1.38-2.19) than those born with normal weight. Boys were 1.27 times (95\% Cl 1.10-1.48) more likely to be stunted than girls. Infants with a history of neonatal illness, they were 1.23 times (95\% Cl 0.99-1.50) more susceptible to stunting. Being poor was another indirect variable that significantly associated with stunting $(\mathrm{OR}=1.3,95 \% \mathrm{Cl} 1.12-1.51)$.
\end{abstract}

Conclusion: LBW, gender (boys), history of neonatal illness and poverty are factors related to stunting among children aged 12-23 months in Indonesia, with LBW being the major determinant of stunting.

Keywords: Stunting, Low birth weight, Indonesia

\section{Background}

Stunting is associated with the higher incidence of degenerative diseases in the later stages of life [1]. Globally, it is estimated that $26 \%$ of toddlers are stunted. Results from the National Basic Health Survey (Riskesdas) 2010 showed that the prevalence of stunting among toddlers and infants was $35.6 \%$ with a higher prevalence rate among infants aged $12-23$ months (40.4\%). The prevalence of stunting ranged from $22.5 \%$ in Yogyakarta to $58.4 \%$ in

\footnotetext{
* Correspondence: aryastami@hotmail.com

${ }^{1}$ Center for Humanities, Health Policy and Community Empowerment, National Institute of Health Research and Development Ministry of Health, J. Percetakan Negara No. 29, Jakarta Pusat 10560, Indonesia

Full list of author information is available at the end of the article
}

East Nusa Tenggara (NTT). This disparity may be caused by the unequal economic development in both provinces [2].

One of the most prominent risk factor for stunting is low birth weight (LBW). LBW is defined as birth weight less than $2500 \mathrm{~g}$. Aside from genetic reasons, LBW is also an indication of premature birth or Intra Uterine Growth Retardation or IUGR [3].

Global statistics reveal that 3.5 million child deaths caused by malnutrition occur annually. Non-exclusive breast feeding is the suspected cause of 1.4 million child deaths and up to $10 \%$ of the illnesses among children. Malnutrition is generally expressed as stunted growth 
and thinness, as a result of IUGR during the mother's pregnancy in addition to improper care after birth [4].

The disparities of the stunting prevalence in Indonesia were obviously related to the underlying economic determinants between the more developed western and less-developed eastern part of Indonesia. However, other important factors such as birth weight, feeding practices, illness during the first 2 years of life and accessibility of health programs intervention are closely related to stunting.

Current data shows that only $15.3 \%$ of Indonesian infants were exclusively breastfed in the first 6 months of their life [2]. Achievements of universal coverage of optimal breast feeding in addition to appropriate complementary feeding practices would reduce more than $15 \%$ of the mortality among children under 5 years of age $[5,6]$. In addition, neonatal illness is another determinant of children's nutritional status.

The objective of this study is to analyze the impact of low birth weight, feeding practices and neonatal illness on the likelihood of stunting among Indonesian infants.

\section{Methods}

\section{Data source and selection}

This cross-sectional study used data from Riskesdas 2010. The Riskesdas is a national basic health survey that has been conducted in 2007, 2010 and 2013. It focused on health indicators mandated by the Millenium Development Goals. Riskesdas was conducted between May and August 2010 covering 33 provinces and 441 districts in Indonesia. The survey was a community based survey using a sample of 70.000 household. Primary data cleaning and analysis were conducted by the National Institute of Health Research and Development Ministry of Health of the Republic of Indonesia.

The data in Riskesdas were collected through stratified random sampling. Census Block (CB) was selected from each district/municipality in proportion to the population size. There were $2800 \mathrm{CBs}$ that were selected randomly from the universe of $\mathrm{CBs}$, with 25 households again randomly selected from each selected $\mathrm{CB}$. The Riskesdas survey contains information for a total of 251,388 individuals from 70,000 households [2].

In this analysis, we included data from subjects aged 12-23 months. We excluded subjects who did not have information on birth weight, history of feeding practices (breast feeding and complementary food), as well as history of neonatal illness since birth. There were 3024 subjects involved in the analysis.

Information about the subjects was collected by interviewing their mother. Some information, for example the LBW was taken from growth monitoring cards. In Indonesia, infants and toddlers are regularly weighed once a month as part of a child growth and nutritional status monitoring program. The data are recorded in a nationally standardized monitoring card.

Anthropometric measurements were taken by enumerators using standardized body length with the precision of $0.1 \mathrm{~cm}$. Enumerators were trained not only for technical interviews, but also to take the anthropometric measurement. Records of the subjects' birth weight was taken either from the monitoring card, or the book that is provided by the health ministry to every pregnant woman in Indonesia for self-monitoring [2].

The enumerators were fresh graduates with healthrelated background such as nurse, midwife, nutritionist and public health. In addition to their education background, they were well trained in class as well as in field trials.

\section{Study variables}

Infants' demographic characteristics (i.e., gender, status of LBW and history of neonatal illness); food intake history (i.e., whether the colostrum was taken, whether the baby had breast-feeding initiated within $1 \mathrm{~h}$ of birth, exclusive breast feeding, received pre-lacteal food, whether the infant was weaned at 1 year of age and received complementary feeding more than 6 months); the exposure to health program/services (i.e., routinely weighed for growth monitoring, complete immunization, and vitamin A supplementation), and the socioeconomic status of the household. LBW status was defined as a birth weight of less than 2500 g. Neonatal illness was defined as whether or not the infants were sick due to any causes up to 28 days after birth.

Colostrum is defined as the thick yellowish substance secreted from the mammary glands after giving birth that is high in protein, fat-soluble, vitamins, minerals and antibodies that can protect the baby from illness [6]. Breastfeeding initiation is defined as the baby being breast-fed less than one hour after birth as recommended by the WHO. Exclusive breast-feeding was defined as the 6 month period after birth during which the child receives no other food or drink, not even water, except breast milk (including milk expressed or from a wet nurse), but allows the infant to receive ORS, drops and syrups (vitamins, minerals and medicines). The cut-off point for age of weaning was defined as 12 months based on the median of the data.

Pre-lacteal food is any food except mother's milk provided to a newborn before initiating breastfeeding. Complementary feeding refers to the process starting when breast milk alone is no longer sufficient to meet the nutritional requirements of infants, and therefore other foods and liquids are needed, along with breast milk [7].

Complete immunization is defined as having received all immunizations as provided by the programs at 1 years of age, namely Hepatitis B (first dose) at the age of 0-7 
days; BCG at the age of one month; Hepatitis B (second dose), DPT (first dose) and Polio (first dose) at the age of 2 months; Hepatitis B (third dose), DPT (second dose) and Polio (second dose) at the age of 3 months; DPT (third dose) and Polio (third dose) at the age of 4 months, and finally Polio (fourth dose) and Measles at the age of 9 months. Infants were categorized as receiving vitamin A supplementation if they receive vitamin A supplementation in the last 6 months prior to the interview.

Socio economic status was assessed using the yearly household expenditures. Quintiles were used to categorize the socio-economic status into five different categories. The two lowest quintiles were categorized as the poor; while the highest quintiles were categorized as the very rich.

Stunting as the outcome was provided in the data set. Calculation of the Z-scores were based on body length by age and converting a child's variables of identification number, gender, age (in months), and body length using WHO anthropometry soft-ware (WHO AnthroII.PC2007). Stunting was defined as a Z-score less than minus two standard deviations (<-2SD) from the median [8].

\section{Statistical analysis}

Data analysis was undertaken using SPSS version 13.0. Normality of the distribution of numerical variables was tested using the Kolmogorov-Smirnov test. Since the distribution was not normal, a binary binomial categorical variable was constructed by classifying as stunted a child with a height for age Z-score less than -2 standard deviations $(\mathrm{HAZ}<-2 \mathrm{SD})$ and as not stunted if $\mathrm{HAZ} \geq-2$ $\mathrm{SD}$. Univariate analysis were used to understand the distribution of the variables. Cross-tabulations were done to analyze the association (Chi-square tests) between stunted and all independent variables, simultaneously with the odd ratios. Finally, multiple logistic regressions were run step by step by selecting the final list of variables used among all candidates based on whether they were significant. All variables with $p<0.20$ were included in the multiple logistics regression using forward selection.

\section{Results}

The total number of subjects was 3,368 infants of age 12-23 month. As much as 344 subjects were excluded from the analysis due to missing information and/or outliers resulting in 3,024 subjects available for the data analysis.

The characteristics of the subjects are described in Table 1 . Most subjects are girls, and about $11 \%$ of the subjects were of low birth weight. Neonatal illness were experienced by $15 \%$ of the subjects. Most infants had received colostrum (65\%), but exclusive breast-feeding until the age of 6 months was only 20\%. Exposure to public health services was low, except for Vitamin A supplementation (76\%). Almost half of the subjects
Table 1 Characteristics of the subjects

\begin{tabular}{|c|c|}
\hline \multirow[t]{2}{*}{ Variables } & N (\%) \\
\hline & $N=3024$ \\
\hline \multicolumn{2}{|l|}{ Child's gender } \\
\hline Boys & $1479(48.9)$ \\
\hline Girls & $1545(51.1)$ \\
\hline LBW status & $325(10.7)$ \\
\hline Had neonatal illness & $445(14.7)$ \\
\hline \multicolumn{2}{|l|}{ Food intake history } \\
\hline Colostrum taken & $1959(64.8)$ \\
\hline Breast feeding initiated less than $1 \mathrm{~h}$ & $1291(42.7)$ \\
\hline Exclusive breast feeding (6 months) & $597(19.7)$ \\
\hline Weaning at $>=1$ year old & $2660(87.9)$ \\
\hline Receive pre-lacteal food & $1572(51.9)$ \\
\hline Had complementary food $<6$ months) & $2071(68.5)$ \\
\hline \multicolumn{2}{|l|}{ Exposure to health program/services } \\
\hline Regularly weighed/growth monitored & $1258(41.6)$ \\
\hline Completed immunization & $1427(47.2)$ \\
\hline Had Vitamin A supplementation & $2290(75.7)$ \\
\hline \multicolumn{2}{|l|}{ Economic status } \\
\hline Quintile 1 & $681(22.5)$ \\
\hline Quintile 2 & $672(22.2)$ \\
\hline Quintile 3 & $668(22.1)$ \\
\hline Quintile 4 & $573(18.9)$ \\
\hline Quintile 5 & $430(14.2)$ \\
\hline Stunting & $1222(40.4)$ \\
\hline
\end{tabular}

(44.7\%) were from households in the bottom two quintiles of the distribution of food expenditures. Stunting was prevalent in $40 \%$ of the subjects.

\section{Infant's characteristics and feeding practices in relation to stunting}

In Table 2, we describe the relationship between the subject characteristics with stunting. LBW has the strongest significant relationship with stunting $(\mathrm{OR}=1.74 ; 95 \% \mathrm{CI}=$ 1.38-2.19); followed by poor economic status $(\mathrm{OR}=1.31$; 95\% CI $=1.30-1.32)$, neonatal illness $(\mathrm{OR}=1.26 ; 95 \% \mathrm{CI}$ $1.03-1.54)$ and being a male child $(\mathrm{OR}=1.24 ; 95 \% \mathrm{CI}=$ $1.07-1.43)$.

There were eight variables entering the analysis to be run for the logistic analysis after the candidate selection, among others: colostrum given $(p=0.156)$, age at first complementary feeding $(p=0.047)$, birth weight $(p=0.001)$, sex $(p=0.002)$, illness at age $0-28$ days $(p=0.034)$, completed immunization $(p=0.091)$, weighed regularly $(p=0.174)$ and socio-economic $(p=0.001)$. Of all these variables only those with significance $p<0.20$ were used in the final analysis. Table 3 presents the estimates from a multivariate logistic regression analysis of the pooled 
Table 2 Relationship of subject characteristics with the stunting

\begin{tabular}{llll}
\hline Characteristics & OR & $95 \% \mathrm{Cl}$ & $\begin{array}{l}\text { Pearson } \\
\text { Chi-square }\end{array}$ \\
\hline Infants characteristics: & & & \\
$\quad$ Boys & 1.24 & $1.068-1.428$ & 0.003 \\
LBW status & 1.74 & $1.382-2.194$ & $<0.001$ \\
$\quad$ Neonatal illness & 1.26 & $1.026-1.539$ & 0.016 \\
Food intake history: & & & \\
$\quad$ Colostrum taken & 0.94 & $0.856-1.023$ & 0.800 \\
$\quad$ Pre-lacteal feeding & 1.08 & $0.930-1.244$ & 0.172 \\
$\quad$ Exclusive breast feeding & 1.11 & $0.923-1.327$ & 0.147 \\
$\quad$ Weaned $\geq 1$ year old & 0.96 & $0.768-1.202$ & 0.385 \\
$\quad$ Early complementary food & 0.87 & $0.745-1.017$ & 0.044 \\
Exposure to health program/services & & & \\
$\quad$ Not weighed regularly & 1.11 & $0.957-1.286$ & 0.090 \\
$\quad$ Not completed immunization & 1.09 & $0.942-1.261$ & 0.130 \\
$\quad$ Not given Vitamin A supplement & 1.06 & $0.899-1.260$ & 0.247 \\
Economic status & & & \\
$\quad$ Poor (Quintile1 \&2) & 1.31 & $1.130-1.524$ & $<0.001$ \\
\hline
\end{tabular}

dataset based on stunting and only four explanatory variables.

The model summary statistic showed that the R-squared of Nagelkerke was $2.3 \%$, meaning $2.3 \%$ of stunted variability can be explained by birth weight, sex, illness history in the first 28 days of life, and poverty. Indeed, this only an estimate since the coefficient determination in the multivariate logistic regression can't be calculated in a manner similar to that in a multivariate linear regression.

The multivariate analysis shows that infants born with LBW were 1.74 times more likely to be stunted $(95 \% \mathrm{CI}=$ 1.38-2.19) than those born with normal weight. Boys were 1.28 times $(95 \% \mathrm{CI}=1.10-1.48)$ more likely to be stunted than girls. Infants with a history of neonatal illness were 1.23 times $(95 \% \mathrm{CI}=0.99-1.50)$ more susceptible to stunting and poor economic status had significant association with stunting (OR 1.30; 95\% CI $=1.12-1.51$ ). There was interaction between LBW and sex as well as LBW and economic status. Analysis for confounders showed that suspected variables of complementary feeding and existence of Neonatal illness was not a significant confounder.

\section{Discussion}

In our study, we found that LBW, gender (boys) and history of neonatal illness and poverty are independently related to stunting among infants in Indonesia. Low birth weight is a predisposing factor to growth attainment after birth. LBW is related to preterm delivery, IUGR or both. In developing countries, like Indonesia, the risks are more often associated with IUGR [9-11]. Several studies have shown that most of infants born with low weight in Indonesia had IUGR $[3,12]$. Previous study by Karima et.al, showed a significant relationship between a mother's nutritional status, weights gained during pregnancy, iron intake and the age of gestation with the incidence of LBW [13]. Evidence suggests that poor early growth retardation coincides with sub-optimal cognitive development and the inhibited growth of internal organs may result in a low cognitive ability and increase risks for chronic diseases in later life [14]. A study in Zimbabwe found that growth of the LBW babies are well behind the growth of normal weight babies and significant length differences were apparent at 12 months of age [15]. Intra uterine growth restriction and/or erratic growth during the first 2 years of life can lead to a lower economic productivity in adult-hood. According to Victora: "Poor fetal growth or stunting in the first 2 years of life leads to irreversible damage, including shorter adult height, lower attained schooling, reduced adult income, and decreased their offspring birth weight" [14]. In addition, stunting as stated by Pojda, is a powerful predictor of infant growth and survival [16].

Breast feeding frequency in addition to good quality breast milk given to infants until the age of 6 months is expected to prevent growth faltering. Appropriate complementary feeding including quality, variety and diversity after the exclusive breast-feeding would further support the growth of an infant. Appropriateness is defined as the correct type of food (semi solid to solid, that includes protein sources), balanced nutrients composition (energy, protein, vitamins and minerals), proper food preparation practices, as well as proper child care [17].

However, growth deficits since birth seem to significantly increases the risk of stunting up until 2 years of life and to contribute to a short stature as well as increasing the risk of developing chronic diseases later in life. A study

Table 3 Multivariate regression analysis of risk factors for stunting

\begin{tabular}{llllll}
\hline \multirow{2}{*}{ Factor } & Estimated & & & \\
\cline { 2 - 6 } & Regression Coefficient $(\beta)$ & SE of $(\beta)$ & $p$-value & Odds Ratio Exp $(\beta)$ & $95 \%$ Cl for Exp $(\beta)$ \\
\hline Constant & -0.606 & 0.085 & 0.000 & 0.545 & 1.740 \\
Low Birth weight & 0.554 & 0.119 & 0.000 & $1.378-2.197$ \\
Boys & 0.245 & 0.075 & 0.001 & 1.278 & $1.103-1.481$ \\
III at age 0-28 days & 0.203 & 0.104 & 0.052 & 1.225 & $0.998-1.503$ \\
Poor & 0.263 & 0.075 & 0.000 & 1.301 & $1.123-1.508$ \\
\hline
\end{tabular}


from Guatemala showed that when the median length of new born babies was $2 \mathrm{~cm}(-1 \mathrm{SD})$ shorter than the standard reference, this difference increases to $9 \mathrm{~cm}(-2$ to -2.7 $\mathrm{SD})$ by the time the baby reaches 2 years of age [18].

In our study, boys have 1.28 times higher risk to be stunted compared to girls. Our finding differs from Kramer et.al who reported that the relative risks of IUGR is 1.19 in girls relative to boys [9]. A previous study using data from Indonesia reports a similar result as ours. Data from some surveys showed that the prevalence of stunting among preschool children was higher for boys compared to girls. The prevalence of stunting among preschool children in Indonesia in 1990 and 2001 for boys was 47.0 and $46.6 \%$, while for girls the prevalence was ranged from 41.9 to $45.5 \%$ [10, 19]. Similarly, relative risk of stunting in boys was 1.65 compare to girls in Kolkata, India [20].

Our analysis showed that after controlling for food given, there was a significant association between neonatal illness and stunting. Infection is an important determinant of infant nutritional status. A study indicated that severe malnutrition is related to high prevalence or incidence of diarrhea [21]. Infectious diseases have an adverse metabolic effect that may influence the amount of food consumed and result in a lower nutritional state [22]. A child who experiences infection may have a higher metabolic rate and therefore need a higher food intake. At the same time, infants have a lower appetite and loose nutrients because of diarrhea and vomiting. Semba in his study in Indonesia found that there was an association between mortality and a history of diarrhea among children less than 5 years of age [23]. A further study mentioned that the risk of stunting is increased when the infants had repeated or prolonged episodes of diarrhea [22].

Colostrum given and pre-lacteal feeding have no significant contribution to stunting. This analysis reveals that infants who were either given colostrum or pre-lacteal feeding are at no risk of being stunted. Exclusive breast feeding until the age of 6 months has no association with stunting either. Meta-analysis showed that the protective effect of breastfeeding may due to confounding with socio-economic status. Women who are higher in socioeconomic status maybe more nutrition-conscious [7]. Along similar lines, the absence of an association in our study between early complementary feeding and stunting may be a reflection of the higher consciousness of mothers toward nutrition.

Low prevalence on exclusive breast-feeding was due to habitual in older time or by older people such as the grandmother by giving breast milk to infants until the age of 4 months as much as possible. The quality of breast milk given is not an important for the mothers. Thus, the nutrients needed by the infants come mostly from complementary foods. In most of the cases, the mothers breastfeeding are undernourished themselves, resulting in low production of breast milk and earlier introduction of complementary foods. Other possible explanations may be that in developing countries, the age of introduction of complementary foods is not associated with stunting, as shown by a study in rural Ethiopia [23].

In our study, stunting is significantly associated with poor economic status. This finding is in accordance with the common hypothesis that poverty leads to LBW and prolonged stunting, independently of other variables [24]. Nevertheless although socio-economic status is associated with risk factors of health, the pathways through which it affects health outcomes remain to be explored [25].

\section{Conclusion}

We showed in our study that LBW, gender (boys), history of neonatal illness and poverty were factors related to stunting among children aged 12-23 months in Indonesia. Among the variables, LBW was the most important and dominant risk factor.

\section{Abbreviations}

BCG: Bacillus calmette guerin; CB: Census block; DPT: Diphteria Pertussis and Tetanus; HAZ: Height for Age Z-score; IUGR: Intrauterine growth restriction; LBW: Low birth weight; NTT: Nusa Tenggara Timur (English: East Nusa Tenggara); ORS: Oral rehydration solutions; Riskesdas: Riset Kesehatan Dasar (English: National Basic Health Research); WHO: World Health Organization

\section{Acknowledgement}

We thank the National Institute of Health Research and Development, Ministry of Health Republic of Indonesia for the permit of utilizing the data-based of Riskesdas 2010. We also thank the HENRI program and all co-supporting agencies for the provision of technical support, including USAID, Harvard School of Public Health, SEAMEO-RECFON Jakarta, Summit Institute of Development and Hellen Keller International. Finally we thank Emmanuel Skoufias for help in proof-reading this paper.

\section{Funding}

Ni Ketut Aryastami received a stipend and support for manuscript preparation and analysis as an Intern with the Higher Education Network Ring Initiative (HENRI) Program, a partnership supported by a grant from the United States Agency for International Development-Indonesia(Cooperative Agreement AID-497-A-11-00002) to the Harvard School of Public Health in partnership with, and with in-kind contributions from, the SEAMEO Regional Centre for Food and Nutrition, University of Mataram, Andalas University, the Summit Institute of Development, and Helen Keller International.

\section{Availability of data and materials}

All of the data supporting our findings are contained within the manuscript. Data will not be shared for these data is kept and protected by the data management section at the National Institute of Health Research and Development, Ministry of Health Rep. of Indonesia. Data can only be taken from that division directly by proposing a new research plan that does not conflict with any previous analysis. No sharing data is permitted.

\section{Authors' contributions}

NKA developed the concept, analysed the data and wrote the manuscript; AS directed the analysis; NK performed data extraction and analysis; BB analysed the data and performed biostatistics interpretation; $A B J$ performed data preparation and analysis; EA interpreted and checked for the data analysis. All authors read and approved the final manuscript. 


\section{Competing interests}

The authors declare that they have no competing interests.

\section{Consent for publication}

Not applicable.

\section{Ethics approval and consent to participate}

Ethical clearance was received from the Ethical Committee of the National Institute of Health Research and Development, Ministry of Health Republic of Indonesia. Permission to access the data in Riskesdas 2010 was given by the National Institute of Health Research and Development, Ministry of Health Republic of Indonesia. Informed consent was provided and has to be signed up well in advance by the subjects for their participation before the interview is conducted.

\section{Author details}

${ }^{1}$ Center for Humanities, Health Policy and Community Empowerment, National Institute of Health Research and Development Ministry of Health, II. Percetakan Negara No. 29, Jakarta Pusat 10560, Indonesia. ${ }^{2}$ Harvard School of Public Health, Harvard University, Boston, MA 02115, USA. ${ }^{3}$ Centre for Public Health Research and Development National Institute of Health Research and Development Ministry of Health, Jakarta, Indonesia. ${ }^{4}$ Department of Biostatistics, School of Public Health University of Indonesia, Depok, West Java, Indonesia. ${ }^{5}$ Department of Nutrition, School of Public Health University of Indonesia, Depok, West Java, Indonesia.

Received: 15 April 2016 Accepted: 24 January 2017

Published online: 07 February 2017

\section{References}

1. Barker DJP, Clark PM. Fetal undernutrition and disease in later life. J Reprod Fertil. 1997;2:105-12.

2. NIHRD. Ministry of Health, Report on Basic Health Research 2010. Jakarta: National Institute of Health Research and Development, Ministry of Health Rep of Indonesia; 2010.

3. Kusharisupeni. The role of birth weight and age of pregnancy towards baby's linear growth at Sliyeg and Gabuswetan sub districts, district of Indramayu, West Java 1995 - 1997, in Graduate Program. Jakarta: University of Indonesia; 1999

4. Black RE, Allen LH, Bhutta ZA, Caulfield LE, de Onis M, Ezzati M, Mathers C, Rivera J. Maternal and child undernutrition: global and regional exposures and health consequences. Lancet. 2008;371:243-60.

5. WHO. Infant and young child feeding: model chapter for textbooks for medical students and allied health professionals. Geneva: WHO Press; 2009. p. 112, ISBN 9879241597494 (NLM classification: WS 125).

6. Hitchcock, H. Colostrum and the Stages of Breast-feeding. 2011 Jul 19, 2011]; Available from: http://www.livestrong.com/article/496122-colostrum-and-thestages-of-breast-feeding/.

7. Horta BL, Bahl R, Martines JC, Victora CG. Evidence on the long-term effects of breastfeeding. Geneva: DHO, Department of Child and Adolescent Health and Development (CAH); 2007.

8. WHO. WHO child growth standards: growth velocity based on weight, length and head circumference: methods and development. 2009.

9. Kramer MS, et al. Socioeconomic disparities in pregnancy outcome: why do the poor fare so poorly? Paediatr Perinat Epidemiol. 2000;14:194-210.

10. Syafiq A. Tinjauan atas kesehatan dan gizi anak usia dini, in Makalah pada Diskusi Peningkatan Kesehatan dan Gizi Anak Usia Dini, Bappenas. Jakarta: Departemen Gizi Kesehatan Masyarakat, FKMUl; 2007.

11. Wu G, Bazer FW, Cudd TA, Meininger CJ, Spencer TE. Maternal nutrition and fetal development. J Nutr. 2004;134:2169-72.

12. Achadi EL, et al. Women's nutritional status, iron consumption and weight gain during pregnancy in relation to neonatal weight and length in West Java, Indonesia. Int J Gynecol Obstet. 1995;48(Suppl):S103-19.

13. Karima K, Achadi EL. Maternal nutritional status and baby's weight at birth. Nat Public Health J. 2012;7(3):111-19.

14. Victora CG, Adair L, Fall C, Hallal PC, Martorell R, Richter L, Sachdev HS. Maternal and child undernutrition: consequences for adult health and human capital: Maternal and Child Undernutrition 2. Lancet. 2008;17(2008):1-18.

15. Mbuya M, Chideme M, Chasekwa B, Mishra V. Biological, Social, and Environmental Determinants of Low Birth Weight and Stunting among
Infants and Young Children in Zimbabwe, in Zimbabwe working paper No. 7. Calverton: ICF Macro; 2010. p. 39.

16. ACC/SCN. Low Birthweight: Report of a Meeting in Dhaka, Bangladesh on 14-17 June 1999. In: Pojda J, Kelley L, editors. Nutrition Policy Paper \#18. Geneva: ACC/SCN in collaboration with ICDDR,B; 2000.

17. Steyn $\mathrm{N}$, et al. Food variety and dietary diversity scores in children: are they good indicators of dietary adequacy? Public Health Nutr. 2006;9(5):644-50.

18. Martorell R, Flores R, Hickey M. Stunting in Guatemala: Analyses of Change Over 15 Years. Atlanta: Department of International Health, Rollins School of Public Health, Emory University; 2002. p. 1-89.

19. Atmarita. Nutrition problems in Indonesia 2005, Directorate of Community Nutrition, The Ministry of Health Republic of Indonesia: An Integrated International Seminar and Workshop on Lifestyle - Related Diseases Gajah Mada University, 19 - 20 March, 2005.

20. Bisai S. Growth pattern and prevalence of underweight, stunting and wasting among infants of Kolkata, West Bengal, India. Internet J Biol Anthropol. 2009;3(2).

21. Kramer M. Determinants of low birth weight: methodological assessment and meta-analysis. Bull World Health Organ. 1987;65(5):663-737.

22. Simondon KB, Simondon F, Costes R, Delaunay V, Diallo A. Breast-feeding is associated with improved growth in length, but not weight, in rural Senegalese toddlers. Am J Clin Nutr. 2001;73:959-67.

23. Umeta $\mathrm{M}$, West $\mathrm{CE}$, Verhoef $\mathrm{H}$, Haidar J, Hautvast JGAJ. Factors associated with stunting in infants age 5-11 months in the Dodota-Sire District, Rural Ethiopia. J Nutr. 2003;133:1064-9.

24. Bradley RH, Corwyn, RF, Socioeconomic status and child development. Annu Rev Psychol. 2002;371-99. Center for Applied Studies in Education, University of Arkansas

25. Blakely T, Hales S, Woodward A. Poverty : assessing the distribution of health risks by socioeconomic position at national and local levels. Geneva: World Health Organization; 2004. (WHO Environmental Burden of Disease Series, No.10).

\section{Submit your next manuscript to BioMed Central and we will help you at every step:}

- We accept pre-submission inquiries

- Our selector tool helps you to find the most relevant journal

- We provide round the clock customer support

- Convenient online submission

- Thorough peer review

- Inclusion in PubMed and all major indexing services

- Maximum visibility for your research

Submit your manuscript at www.biomedcentral.com/submit
) Biomed Central 